Historic, Archive Document

Do not assume content reflects current scientific knowledge, policies, or practices. 



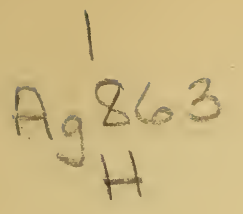

SPECIAL.

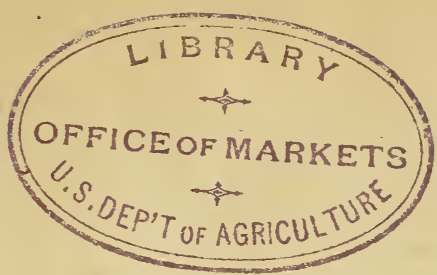

Issued November $25,1914$.

U. S. DEPARTMENT OF AGRICULTURE.

OFFICE OF THE SECRETARY.

\section{HORSE AND MULE RAISING IN THE SOUTH.}

\section{PREPARED IN THE BUREAU OF ANIMAL INDUSTRY.}

There is no single factor in agricultural production on the average farm that is of greater importance than good horse or mule power. This power can usually be furnished more cheaply by the production of needed animals in that particular locality than by purchasing them from remote localities. In home production there is also the added advantage of possessing animals which are thoroughly acclimatized. Therefore if you are the owner of a good mare do not fail to breed her either to a good stallion or a good jack.

If the mare is of the light type, breed her to a good stallion of one of the light breeds; and if of a draft type, breed her to a draft stallion. The progeny of a light mare bred to a draft stallion or of a draft mare to a light stallion is usually a nondescript that is not fitted to any particular field and will not command the price of either a high-class light or a high-class draft horse. By the light type is meant horses of the Standardbred, Thoroughbred, American Saddle, and similar breeds; by the draft type is meant horses of the Percheron, Belgian, Shire, Clydesdale, and similar breeds. In breeding to a jack, mares of almost any kind may be used if sound, the best mules, as a rule, being produced from the mares with the most weight and finish. The production of inferior animals of any kind is seldom profitable.

The destruction of horses in the countries now at war is enormous, and when peace is declared and for many years thereafter there will no doubt be a great demand for horses for agricultural and other work. The farmer who has surplus horses at that time will be in a position to obtain good prices. Keep your best mares to work on the farm and raise colts at the same time. You will thus be in position not only to raise horses for your work but also to take advantage of the home and foreign markets.

\section{CARE OF THE BROOD MARE AND FOAL.}

Many brood mares are overworked, while many others are kept too closely confined. The mare may be safely worked to within two

NoTE.-Intended for farmers in the cotton belt who desire tordiversify their farming because of the economic crisis which adversely affects the cott ${ }^{\circ}$ crop at this time.

$70335^{\circ}-14$ 
weeks of foaling if good care is used to see that she is not overworked or injured in some other way. It is not unusual for mares which have been worked to the date of foaling to foal successfully. It is safer, however, to diminish the work gradually so that during the last few weeks only the lightest kind of work is done.

If pasture is available, the mare mon be turned out about two weeks before foaling. If pasture is not available, she should be given a good roomy box stall. There need be no radical change in the feed, except that the ration of the mare should be lightened shortly before foaling and made more laxative. For this purpose an addition of bran and a decrease of other grain feeds is very satisfactory.

When the mare is again put to work the foal may either be left in the stable or allowed to follow. If left in the stable, it will be necessary to return the mare in the middle of the forenoon and likewise in the afternoon for the colt to suck. Never allow the foal to suck when the mare is very warm, for the milk at that time is quite apt to cause digestive disorders in the colt. The foal should be allowed access to the dam's grain in order that it may learn to eat as soon as possible. The foal may be weaned at 6 months of age, and if it has previously been eating grain, no great setback will occur.

The mare can usually be bred with greater certainty of success on the ninth day after foaling than at any subsequent date.

\section{CARE OF THE FOAL AFTER WEANING.}

As exercise is of prime importance for the proper development of young animals, the foal should have pasture or a paddock in which to exercise. Access to a barn or shed should be provided as a protection against storms.

The feed of the foal may be similar to that which the mare was receiving before the foal was weaned. The weaned foal should have 2 to 3 pounds of grain per day and what hay it will eat. A grain mixture consisting of two parts of ground oats, two parts of corn meal, and one part of wheat bran, by weight, may be fed. If oats and bran are not available a mixture consisting of seven parts corn ineaI and one part cottonseed meal may be substituted. Áll of the leguminous hays, if of a good quality, such as alfalfa, clover, and cowpea hay, are good for the foal. As the foal becomes older a more liberal grain ration should be provided. A yearling foal, to grow properly, will need 4 or 5 pounds of grain per day in addition to what hay will be eaten.

\section{FEEDING THE WORK HORSES AND MULES.}

The selection of a ration for horses and mules depends largely upon the kinds of feed available, the prices of the same, and the amount and character of the work. For a 1,000 or 1,100 pound horse at moderate work a daily ration of from 10 to 12 pounds of grain and from 12 to 14 pounds of hay should be ample. At light work the grain ration should be less, and at particularly heavy work the amount of grain should be increased. For a horse at moderate work weighing from 1,000 to 1,100 pounds the following rations will be found satisfactory. These rations are to be divided into three 
feeds. Nearly one-half of the roughage should be fed at night and the remainder divided between the morning and noon feeds. The grain may be divided into three equal portions, to be fed morning, noon, and night.

10 pounds oats.

14 pounds mixed hay (Bermuda, lespedeza, etc.).

10 pounds shelled corn or corn meal or $12 \frac{1}{2}$ pounds ear corn or corn-and-cob meal.

14 pounds cowpea hay.

8 pounds shelled corn or corn meal or 10 pounds ear corn or corn-and-cob meal.

1 pound cottonseed meal.

10 pounds alfalfa hay.

2 quarts molasses.

8 pounds shelled corn or 10 pounds ear corn or corn-and-cob meal.

$1 \frac{1}{2}$ pounds cottonseed meal.

14 pounds mixed hay (Bermuda, lespedeza, etc.).

6 pounds shelled corn or corn meal or $7 \frac{1}{2}$ pounds ear corn or corn-and-cob meal.

2 pounds gluten.

$1 \frac{1}{2}$ pounds cottonseed meal.

6 pounds cowpea hay.

10 pounds corn stover.

The above rations are offered as suggestions and will have to be altered to suit conditions. If an animal is not doing well and is thin in flesh add more grain.

It may be found desirable to feed ear corn instead of shelled corn or corn meal. The ear corn, if desirable, may be ground and fed as corn-and-cob meal. One hundred pounds of ear corn or corn-andcob meal is equivalent to about 80 pounds of shelled corn or corn meal.

For horses at light work the grain in the above rations should be reduced and the roughage increased in amount.

For wintering horses which have little, if any, work to do the foregoing rations may be used, with the grain reduced one-half or threefourths, or the grain may be entirely eliminated if the hay is of good quality and the horses are easy keepers.

Salt should be provided so that the horse may have access to it daily.

Horses should not be fed or watered when they are hot. If a horse comes in very hungry it is better to allow him to eat hay for half an hour before he is given his grain. If he takes the sharp edge off his appetite on hay he will take more time to eat his grain and will masticate it better. In hot weather horses should be watered in the morning, in the middle of the forenoon, before and after their dinner, and before and after their evening meal.

If possible, after the horses have finished their evening feed, they should be turned out in a lot where they can roll and get water at will during the night. This applies especially during hot weather.

As pointed out previously, the selection of a ration and the general care of horses depends quite largely on local corditions, and if the 
reader will get in touch with the county demonstration agent the latter may be of considerable assistance in advising the best methods of handling the stock. In case there is not an agent in your county, write to your State agricultural experiment station for information regarding the most economical rations to be fed in your locality. The following Farmers' Bulletins may be obtained free of charge by writing to the Department of Agriculture, Washington, D. C.:

No. 170. Principles of Horse Feeding.

No. 619. Breeds of Draft Horses. 